\title{
Keragaman Organisme Pengganggu Tanaman (OPT) pada Tanaman Padi Varietas Unggul Baru (VUB) dan Varietas Lokal pada Percobaan Semi Lapangan
}

\author{
Sri Sudewi ${ }^{{ }^{*}}$, Ambo Ala ${ }^{2}$, Baharuddin ${ }^{3}$, dan Muhammad Farid ${ }^{4}$ \\ ${ }^{1}$ Departemen Agroteknologi, Fakultas Pertanian, Universitas Alkhairaat \\ ${ }^{1}$ Program Studi Ilmu Pertanian, Sekolah Pascasarjana Universitas Hasanuddin \\ ${ }^{2,4}$ Departemen Agroteknologi, Fakultas Pertanian, Universitas Hasanuddin \\ ${ }^{3}$ Departemen Hama dan Penyakit Tumbuhan, Fakultas Pertanian, Universitas Hasanuddin \\ *Alamat korespondensi: srisudewirahim@gmail.com
}

\begin{abstract}
Diversity of plant pests in rice plants of new superior varieties and local varieties in semi-field experiments
\end{abstract}

Attack of plant pests on rice plants if not treated seriously will significantly reduce plant productivity. The diversity of pests that attack local rice varieties and new improved varieties is very important to know so that more effective and efficient control measures can be taken. The study was conducted in August to February 2018, at the Teaching Farm of the Faculty of Agriculture, Hasanuddin University, Makassar. The method used in this semi-field experiment was observing directly the types of pests that attack rice plants, the symptoms and calculating the percentage of attacks. Observations were carried out every day, starting at the age of \pm 30 days after planting. The results showed that the pests that attacks new superior and local varieties was Locusta migratoria, Sesamia inferens, Cnaphalocrosis medinalis and bacterial leaf blight (BLB) pathogen. The highest attack percentage was found in Inpari 16 and Inpari 42 which imfected by BLB pathogen reaching 50\% while BLB infection at the local varieties of Kamba observed at the value of $\leq 25 \%$. Nilaparvata lugens were only found in Inpari 16 . The results can be used as a reference and source of information so that management and control techniques can be carried out appropriately, quickly, efficiently and effectively.

Keywords: Inpari 16, Inpari 42, Kamba local variety, Pest attack

\begin{abstract}
ABSTRAK
Serangan Organisme Pengganggu Tanaman (OPT) pada tanaman padi apabila tidak ditangani dengan serius akan menurunkan produktivitas tanaman secara signifikan. Keragaman OPT yang menyerang tanaman padi varietas lokal dan varietas unggul baru (VUB) sangat penting untuk diketahui agar dapat dilakukan tindakan pengendalian yang lebih efektif dan efisien. Penelitian dilaksanakan pada bulan Agustus sampai Februari 2018, di Teaching Farm Fakultas Pertanian Universitas Hasanuddin Makassar. Metode yang digunakan pada percobaan semi lapangan ini dengan mengamati secara langsung jenis OPT yang menyerang rumpun tanaman padi, gejala serangan yang ditimbulkan serta menghitung persentase serangan. Pengamatan dilakukan setiap hari, sejak tanaman berumur \pm 30 hari setelah tanam. Hasil penelitian menunjukkan bahwa OPT yang menyerang VUB dan varietas lokal yaitu Locusta migratoria. L, Sesamia inferens, Cnaphalocrosis medinalis serta patogen penyakit hawar daun bakteri (HDB). Persentase serangan tertinggi terdapat pada VUB Inpari 16 dan Inpari 42 yang terserang HDB mencapai 50\% sedangkan varietas lokal Kamba memiliki reaksi ketahanan yang lebih baik dengan persentase serangan $\leq 25 \%$. Serangan Nilaparvata lugens hanya ditemukan pada varietas Inpari 16. Hasil penelitian ini dapat dijadikan referensi dan sumber informasi agar pengelolaan dan tehnik pengendalian dapat dilakukan secara tepat, cepat, efisien dan efektif.
\end{abstract}

Kata Kunci: Inpari 16, Inpari 42, Varietas lokal Kamba, Serangan OPT 


\section{PENDAHULUAN}

Padi (Oryza sativa L.) merupakan salah satu tanaman pangan yang dibudidayakan oleh sebagian besar masyakarat di Indonesia dengan mengonsumsi beras sebagai makanan pokoknya. Konsumsi rumah tangga beras secara nasional mencapai 96,82\% (Supriyanto, 2019). Tingginya konsumsi beras disebabkan oleh cara berpikir masyarakat Indonesia yang menganggap bahwa beras adalah makanan pokok utama, sehingga muncul pernyataan "belum makan jika belum makan nasi". Kebutuhan akan makanan pokok ini terus mengalami peningkatan seiring dengan pertambahan jumlah penduduk sehingga memunculkan kekhawatiran akan terjadinya keadaan krisis pangan di masa akan datang. Sebagian besar petani melakukan penanaman padi tidak lagi dua kali dalam setahun, tetapi dilakukan tiga kali sepanjang tahun. Musim tanam di Indonesia secara umum dibedakan atas dua yaitu Musim Kemarau (Mei-September) dan Musim Hujan (Oktober-April), namun saat sekarang sering terjadi perubahan pola iklim yang tentunya akan berpengaruh terhadap produksi pertanian. Salah satunya usaha peningkatan produksi beras yang sering mengalami kendala, variabilitas iklim dan cuaca yang tidak menentu memengaruhi keberadaan dan besarnya tingkat serangan hama dan penyakit tumbuhan (HPT) padi, dimana HPT cenderung berkembang pesat di lokasi dengan kondisi perubahan iklim yang ekstrim.

Penurunan produksi padi yang disebabkan kondisi perubahan iklim yang ekstrim (awal musim hujan dan musim kemarau yang tidak teratur) dan adanya serangan dan perkembangan HPT yang meningkat merupakan masalah yang sangat serius dalam budidaya tanaman padi karena dapat mengakibatkan gagal panen. Dikaitkan dengan upaya peningkatan produksi tanaman, pendapatan petani, daya saing produksi, dan pelestarian lingkungan maka diperlukan suatu tehnik pengendalian OPT yang tepat dan fokus pada prinsip bahwa sistem pengendalian di suatu wilayah dapat dilakukan secara cepat, tepat, efektif dan efisien serta berwawasan lingkungan.

Pemilihan varietas yang tepat dan unggul merupakan hal yang penting dalam budidaya tanaman padi agar dapat memberikan hasil sesuai yang diharapkan. Penggunaan varietas yang berbeda akan memberikan hasil yang berbeda pula pada pertumbuhan dan hasil tanaman.

Varietas lokal Kamba merupakan tanaman padi sawah lokal aromatik dengan umur panen 5-6 bulan yang secara turun temurun dibudidayakan oleh petani Lembah Bada Kabupaten Poso (Putra dkk., 2014). Tekstur yang pulen dan lembut, rasanya enak, aroma pandan dan tahan basi ketika sudah ditanak merupakan ciri khas dari beras Kamba sehingga beras ini memiliki daya tarik tersendiri dalam meningkatkan selera makan bagi konsumen (Arzam dkk., 2017). Penggunaan varietas unggul baru (VUB) merupakan teknologi inovatif yang mudah dan murah dalam upaya pencapaian potensi hasil yang tinggi, terutama jika VUB tersebut tahan terhadap organisme pengganggu tanaman (OPT) dengan berbagai cekaman lingkungan biotik maupun abiotik (Suparwoto dkk., 2017).

Informasi mengenai keragaman hama dan penyakit pada padi VUB dan varietas lokal hingga saat ini belum banyak dilaporkan, padahal informasi ini penting untuk diketahui dalam rangka pengendalian OPT untuk menyangga stabilitas produksi padi (Nuryanto, 2018). Oleh sebab itu inventarisasi HPT pada tanaman padi dengan berbagai kultivar tersebut perlu dilakukan agar pengelolaan dan tehnik pengendalian dapat dilakukan secara tepat, cepat dan akurat untuk menjaga apabila terjadi kecenderungan peningkatan populasi atau bahkan kerusakan tanaman padi akibat serangan OPT. Diharapkan hasil penelitian ini dapat berguna sebagai bahan referensi dan sumber informasi jenis-jenis hama dan penyakit yang menyerang padi VUB dan varietas lokal dalam percobaan semi lapangan.

\section{BAHAN DAN METODE}

Penelitian ini dilaksanakan pada bulan Agustus 2018 hingga Februari 2019, bertempat di Teaching Farm Fakultas Pertanian, Universitas Hasanuddin Makassar. Varietas padi yang digunakan dalam penelitian ini adalah dua varietas unggul baru yaitu Inpari 16 dan Inpari 42 serta varietas lokal Kamba. Ketiga varietas benih padi terlebih dahulu disemaikan di tempat persemaian. Umur 14 hari setelah semai, bibit dipindahkan ke dalam masing-masing media tanam (ember yang berisi tanah) dengan jumlah 81 ember untuk tiap varietas sehingga total keseluruhan sampel tanaman yang digunakan adalah 243.

Percobaan semi lapangan dilakukan dalam green house yang di-design menggunakan rangka bambu dengan bagian atap menggunakan plastik UV 14\% (Gambar 1). Paranet (anyaman jaring plastik) digunakan untuk menutupi seluruh bagian sisi dinding, sehingga tidak ada celah. Green house yang 
dikonstruksi berfungsi untuk memberikan kondisi lingkungan mikroklimat yang optimal bagi pertumbuhan tanaman.

Metode yang digunakan pada penelitian ini adalah dengan mengamati secara langsung jenis hama dan penyakit yang menyerang. Pengamatan dilakukan setiap hari, dimulai pada saat tanaman berumur \pm 30 hari setelah tanam. Pengamatan OPT tanaman padi dilakukan dengan mengamati tiap tanaman yang terserang, dengan mengidentifikasi jenis dan gejala serangan di lokasi tersebut.
Persentase serangan dilakukan dengan mengamati sampel tanaman, kemudian menghitung jumlah tanaman yang terserang. Untuk menghitung persentase serangan digunakan rumus:

$$
\mathrm{S}=\frac{\mathrm{n}}{\mathrm{N}} \times 100 \%
$$

Keterangan:

$\mathrm{S}=$ Persentase tanaman terserang

$\mathrm{n}=$ Jumlah rumpun tanaman terserang

$\mathrm{N}$ = Jumlah rumpun tanaman yang diamati

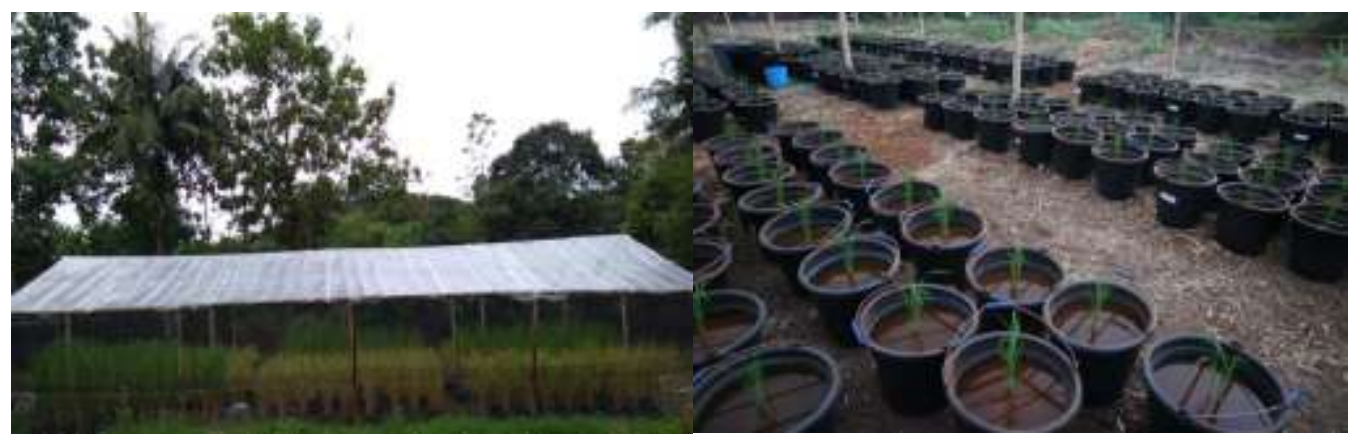

Gambar 1. Green house yang disiapkan di dalam penelitian dan tata letak percobaan

\section{HASIL DAN PEMBAHASAN}

Berdasarkan pengamatan di lapangan, jenis OPT yang menyerang tanaman padi VUB dan varietas lokal disajikan pada Gambar 2. Hasil penelitian menunjukkan bahwa OPT yang menyerang VUB dan varietas lokal saat fase pertumbuhan vegetatif yaitu Locusta migratoria, Sesamia inferens, Nilaparvata lugens dan patogen penyakit hawar daun bakteri (HDB) sedangkan Cnaphalocrosis medinalis menyerang tanaman padi saat fase pertumbuhan generatif (fase pembungaan).

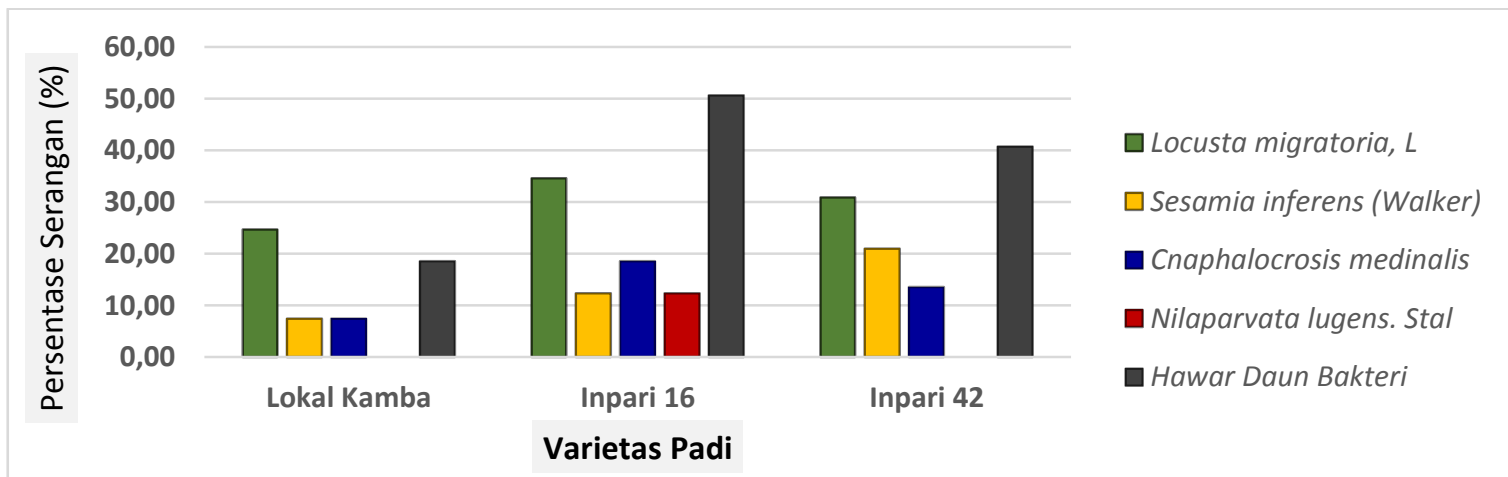

Gambar 2. Persentase tingkat serangan jenis OPT pada tiga varietas padi yang diuji (Lokal Kamba, Inoari 16 dan Inpari 42).

\section{Belalang Kembara (Locusta migratoria L.)}

Serangga yang merupakan salah satu hama penting dan menjadi faktor penghambat dalam meningkatkan produksi tanaman padi dan menyerang semua varietas tanaman padi yang berada di lokasi penelitian adalah belalang kembara (Locusta migratoria) (Gambar 3). Varietas lokal Kamba terserang hama ini dengan persentase serangan sebesar 24,69\% sedangkan VUB Inpari 16 dan Inpari 42 masing-masing sebesar $34,57 \%$ dan $30,86 \%$ (Gambar 2). Adanya gejala serangan dimulai pada saat fase pertumbuhan vegetatif dengan gejala serangan yang terlihat dari bagian daun pertama yang robek akibat gigitan dari hama ini. Hasil yang diperoleh menunjukkan bahwa hama L. migratoria bermunculan dan hinggap di daun tanaman padi 
pada waktu sore hari hingga menjelang malam hari. Dilaporkan bahwa L. migratoria memiliki kebiasaan memakan dan hinggap di daun pada waktu sore hari dan malam hari sampai pagi hari sebelum terbang (Nik dkk., 2017).

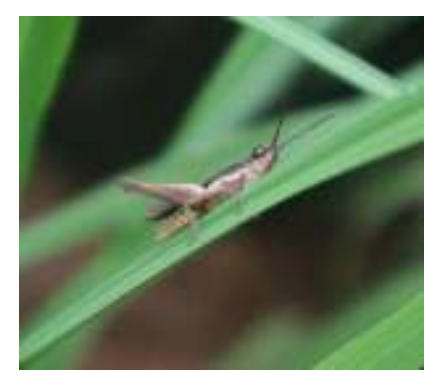

Gambar 3. Nimfa belalang kembara (L. migratoria).

Ledakan populasi belalang kembara dapat menimbulkan kerugian dalam skala besar, karena jika serangannya parah maka daun-daun tanaman padi akan tersisa tulang daunnya saja dan tentunya akan berdampak pada penurunan produktivitas tanaman padi. Belalang yang menyerang tanaman padi baik padi VUB maupun padi lokal di lokasi penelitian, diduga berasal dari populasi tanaman yang terdapat di sekitar lokasi yang banyak ditumbuhi jenis gulma berdaun lebar, tanaman jagung dan tanaman sorghum. Jenis-jenis tanaman ini yang merupakan sumber makanan bagi belalang untuk bertahan hidup.

Selain itu, metamorphosis tidak sempurna dari belalang yang dimulai dari telur-nimfa-imago yang mana belalang betina meletakkan telurnya di dalam tanah hingga menetas, sehingga walaupun di sekililing lokasi penelitian telah dipasangi paranet tetapi ada kecenderungan telur-telur belalang telah menetas menjadi nimfa pada saat awal melakukan penelitian. Nimfa belalang ini dengan mudahnya berpindah mencari sumber makanan baru yang masih segar untuk melangsungkan proses daur hidupnya, sehingga semakin banyak keanekaragaman populasi tanaman yang terdapat di sekitar lokasi penelitian akan berdampak pada melimpahnya keberadaan hama belalang tersebut. Sejalan dengan hasil penelitian Prakoso (2017) bahwa struktur vegetasi yang berbeda pada kedua ekosistem yang berbeda akan berpengaruh terhadap jumlah spesies belalang di masing-masing ekosistem. Ekosistem hutan tanaman memiliki biodiversitas belalang yang lebih tinggi dibandingkan agroekosistem tanaman jagung.

Belalang memiliki tabiat suka berpindahpindah untuk mencari makanan (Maghfiratul dkk., 2017) yang berada di sekitar lokasi yang dilaluinya dan cenderung memilih jenis makanan yang menjadi favorit yaitu jenis tanaman yang termasuk dalam family Graminae atau suku rumput-rumputan (jagung, padi, sorghum) sehingga dengan sangat mudah dapat menyebar pada areal yang luas (Nik dkk., 2017).

Selain faktor keanekaragaman populasi tanaman yang dapat memengaruhi keberadaan dan intensitas serangan belalang, faktor varietas juga sangat menentukan. Varietas unggul baru dan varietas lokal Kamba memiliki tingkat ketahanan yang berbeda. Dari hasil pengamatan dilapangan varietas Inpari 16 dan Inpari 42 lebih rentan terhadap serangan hama belalang. Hal ini dibuktikan dengan banyaknya rumpun tanaman yang robek.

Pengendalian secara mekanik yang dilakukan adalah dengan menangkap dan memusnahkan nimfa belalang yang berada di sekitar rumpun tanaman, melakukan sanitasi lingkungan (membersihkan gulma-gulma yang tumbuh di sekitar lokasi penelitian). Pengendalian secara kimia tidak dilakukan karena populasi nimfa belalang masih mudah untuk dikendalikan, oleh karena nimfa belalang memiliki kemampuan terbang yang terbatas sehingga mudah untuk ditangkap menggunakan jaring.

Terjadinya penurunan populasi belalang di lokasi penelitian, seiring dengan telah dipanennya tanaman lain (sorghum dan jagung) serta rumputrumputan di sekitar lokasi telah dibersihkan, dan juga diduga kondisi iklim yang telah memasuki musim penghujan sehingga telur-telur yang berada dalam tanah tidak menetas lagi. Sebagaimana diketahui bahwa telur belalang akan tetap tersimpan di dalam tanah hingga berbulan-bulan lamanya dan akan menetas kembali saat musim panas tiba.

\section{Penggerak Batang Padi Merah Jambu (Sesamia inferens Walker)}

Hama penggerek batang padi merah jambu atau biasa juga disebut pink borer dari hasil penelitian ini, menyerang varietas Inpari 16 dan Inpari 42 dengan persentase serangan sebesar $12,35 \%$ dan 20,99\%, sedangkan varietas lokal Kamba dengan persentase serangan terendah yaitu 7,41\% (Gambar 2). Serangan pada ketiga varietas terjadi pada saat fase pertumbuhan vegetatif. VUB yang terlebih dahulu terserang dibandingkan padi lokal Kamba, sehingga dapat dikatakan bahwa varietas lokal lebih tahan terhadap serangan hama $S$. inferens. Hal ini sejalan dengan Baehaki (2013) bahwa sebesar 31,68 kg GKP/ha kehilangan hasil padi varietas yang berumur pendek pada setiap 
kenaikan $1 \%$ masing-masing serangan sundep maupun beluk, sedangkan kehilangan hasil sebesar $0,8 \%$ setiap kenaikan $1 \%$ serangan beluk untuk varietas yang berumur panjang.

Berdasarkan pengamatan di lapangan hama ini ditandai dengan adanya larva yang memakan pucuk daun termuda kemudian larva masuk ke bagian tengah daun sehingga daun padi menjadi kuning dan bagian tengah daun tersebut sangat mudah dicabut. Pupa dapat ditemukan di dalam batang (Gambar 4). Hama ini termasuk hama penting tanaman padi pada saat musim penghujan. Curah hujan dan suhu yang lembab berpengaruh terhadap keaktifan dan perkembangbiakan hama penggerek batang padi merah jambu. Kondisi tanah yang lembab akan meningkatkan ketersediaan air yang tentunya akan sangat berguna bagi perkembangan larva penggerek batang padi ini. Menurut Aryantini dkk. (2015) suhu dan kelembaban yang tinggi merupakan faktor yang sangat penting bagi penetasan telur dan perkembangan larva hama penggerek batang padi.

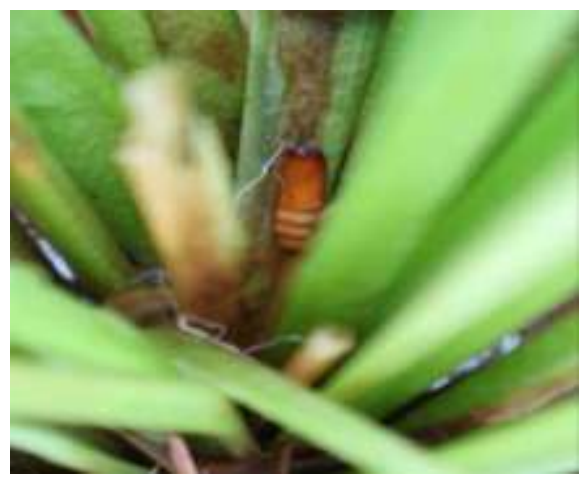

Gambar 4. Pupa penggerek batang padi merah jambu.

Ada empat jenis hama penggerek batang padi yang sering dijumpai pada lahan sawah yakni hama penggerek batang padi kuning (Shcircphophaga incertulas), penggerek batang padi putih ( $S$. innotata), penggerek batang padi bergaris (Chilo suppressalis), dan penggerek batang padi merah jambu (Sesamia inferens). Dilaporkan bahwa hama penggerek batang padi kuning yang sepanjang tahun paling dominan dapat dijumpai di ekosistem sawah dibandingkan hama penggerek batang padi yang lainnya (Aryantini dkk., 2015; Hadi dkk., 2015).

Titik tumbuh tanaman muda berubah warna menjadi coklat, kering lalu mati merupakan gejala dari serangan hama penggerek batang padi pada fase vegetatif yang biasa disebut dengan sundep (deadhearts) gejala akan nampak pada empat hari sejak larva penggerek batang masuk (Gambar 5). Larva kemudian memotong bagian tengah anakan. Selanjutnya apabila terjadi gejala malai mati, berubah warna menjadi coklat dan bulir padi yang dihasilkan hampa. Hal tersebut merupakan gejala serangan penggerek batang padi yang dikenal dengan istilah beluk (whiteheads) menyerang pada fase generatif. Seekor larva hingga berubah menjadi ngengat dapat menghabiskan 6 sampai 15 batang tanaman padi. Larva penggerek batang padi memiliki tabiat suka keluar masuk batang padi (Baehaki, 2013).

Adanya serangan hama $S$. inferens di lokasi penelitian disebabkan oleh vegetasi tanaman yang ada di sekitar lokasi penelitian yaitu jagung dan sorghum, yang diduga merupakan inang alternatif dari hama penggerek batang padi merah jambu sehingga hama ini menyebar secara luas. Sebagaimana diketahui bahwa S. inferens ini bersifat polifag dan dapat hidup dari tumbuhan familygraminae dan cyperaceae. Faktor lain yang berpengaruh adalah kondisi wilayah tempat penelitian yang memasuki musim hujan yaitu bulan November, sehingga suhu dan kelembaban meningkat. Selain itu faktor pemupukan juga berpengaruh, karena kurangnya dosis pupuk kalium yang digunakan sehingga batang tanaman padi menjadi kurang kokoh (tidak keras) akibatnya sangat rentan diserang oleh hama ini.

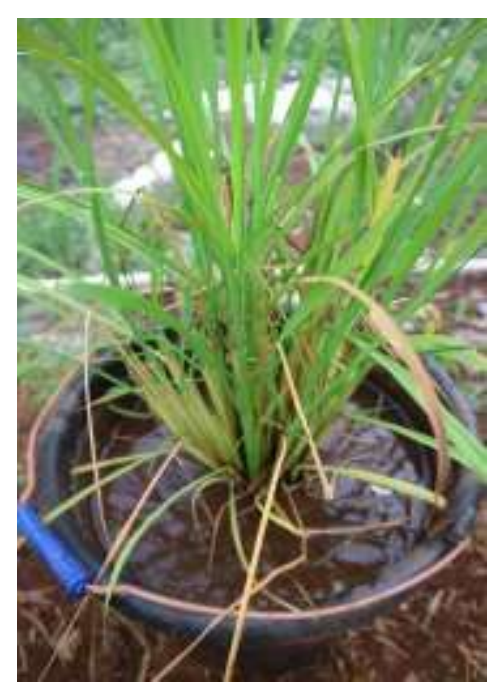

Gambar 5. Gejala serangan $S$. inferens pada fase vegetatif (sundep)

Adapun pengendalian secara mekanik yang dilakukan pada saat penelitian yaitu mengumpulkan kelompok telur yang berada di daun tanaman padi, memeriksa satu-persatu batang tanaman yang terserang, kemudian mencabut dan memusnahkan batang tersebut bersama larva maupun pupanya. 
Selain itu cara lain yang dilakukan adalah dengan membiarkan tanaman padi tersebut selalu tergenang air setinggi $10 \mathrm{~cm}$ dengan tujuan agar larva dan pupa mati karena terendam air.

Pengendalian secara kimiawi dengan menggunakan insektisida tidak dilakukan karena hama ada di dalam batang. Sebagaimana dilaporkan oleh Rahmawati dan Slamet-Loedin (2006) bahwa telur hama penggerek batang padi yang berkembang di dalam batang tanaman sulit dikendalikan dengan menggunakan pestisida. Setelah dilakukan pengendalian secara mekanik terjadi penurunan populasi dan secara berangsur-angsur hama penggerek batang padi merah jambu musnah, sehingga kehilangan hasil akibat serangan hama ini tidak signifikan oleh karena serangan terjadi pada fase vegetatif, yang mana tanaman masih dapat membentuk anakan baru.

Pengendalian juga dapat dilakukan dengan memanfaatkan musuh alami. Dilaporkan bahwa penanaman tanaman-tanaman berbunga di sekitar sawah akan menguntungkan bagi serangga musuh alami dalam hal tersedianya sumber makanan (berupa nectar) yang dapat dimanfaatkan oleh serangga tersebut, sehingga dengan adanya musuh alami akan mampu menekan populasi dari hama penggerek batang padi. Pemanfaatan agens hayati merupakan salah satu alternatif dalam mengendalikan hama penggerek batang padi. Seperti yang dilaporkan oleh Rahmiyati (2006) cendawan Beauveria bassiana dengan konsentrasi $10^{-7}$ dapat mengendalikan hama penggerek batang padi putih.

\section{Hama Putih Palsu (Cnaphalocrosis medinalis Guenee)}

Cnaphalocrosis medinalis menyerang tanaman padi varietas lokal Kamba, Inpari 16 serta Inpari 42 dengan persentase tingkat serangan masing-masing sebesar 7,41\%, 18,52\% dan 13,58\% (Gambar 2). Hama ini menyerang pada saat fase generatif (pembungaan), di antara ketiga varietas yang lebih dulu terserang adalah padi VUB. Hal ini diduga karena perbedaan umur tanaman masingmasing varietas. Perbedaan varietas dan umur tanaman berkorelasi positif terhadap bervariasinya serangan $C$. medinalis pada lokasi persawahan (Kilala dkk., 2015; Surtikanti, 2011).

Berdasarkan hasil pengamatan di lapangan, gejala serangan dari hama ini menyebabkan daun padi VUB dan varietas lokal menjadi terlipat/tergulung dan ditemukannya larva di dalam daun tersebut sehingga menyebabkan terbentuknya garis-garis putih transparan (Gambar 6). Larva yang ditemukan pada ketiga varietas ini tergolong rendah, karena hanya ada beberapa daun tanaman yang terserang. Walaupun hama ini tidak menyebabkan kerugian besar pada usaha budidaya tanaman padi, namun akan menjadi masalah yang serius jika kerusakan terjadi mencapai $\geq 50 \%$ pada fase pematangan. Sekalipun serangan oleh hama $C$. medinalis ini sangat parah kerugian yang ditimbulkan $\geq 10 \%$.

Serangan C. medinalis di lokasi penelitian diduga karena kondisi di sekitar lokasi penelitian yang lembab sehingga disukai oleh beberapa jenis hama. Selain itu faktor semakin banyaknya jumlah daun tanaman yang terbentuk (rimbun) setelah mencapai fase anakan maksimum, memberikan keuntungan bagi serangga sebagai tempat berteduh. Tangkilisan dkk. (2013) dan Baehaki (2005) melaporkan rimbunnya suatu tanaman merupakan tempat yang cocok bagi serangga-serangga tertentu untuk berteduh, bersembunyi dari serangan musuh alami dan berlindung dari paparan sinar matahari.

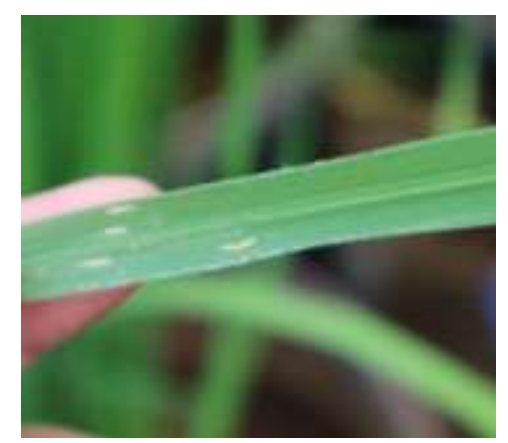

$$
\begin{aligned}
& \text { Gambar 6. Gejala serangan oleh larva } \\
& \text { Cnaphalocrosis medinalis berupa daun } \\
& \text { padi yang melipat. }
\end{aligned}
$$

Tehnik pengendalian yang dilakukan adalah dengan memusnahkan larva-larva yang melekat pada daun tanaman yang terlipat. Selanjutnya melakukan pengeringan pada masing-masing ember yang tanamannya memperlihatkan gejala dengan tujuan untuk mengurangi kelembaban di sekitar tanaman padi.

\section{Wereng Batang Coklat (Nilaparvata lugens Stal)}

Salah satu hama penting yang menyerang tanaman padi di Indonesia adalah wereng batang coklat (WBC) (Ningsih dkk., 2016). Hama ini mengisap cairan sel tanaman sehingga proses penyebaran hasil fotosintesis (berupa sukrosa) ke seluruh bagian tanaman menjadi terhambat dan mengakibatkan tanaman menjadi rusak, kering, hampa dan gagal panen (Harini et al., 2013; Darmadi \& Alawiyah, 2018). Nilaparvata lugens menyerang 
tanaman padi varietas Inpari 16 saat fase pertumbuhan vegetatif dengen persentase serangan sebesar 12,35\%. Gejala serangan yang ditimbulkan yaitu terjadi kerusakan pada daun padi sehingga tampak menguning dan agak mengering sedangkan pada varietas Inpari 42 dan varietas lokal Kamba yang diamati tidak ditemukan adanya gejala serangan ataupun populasi wereng pada batang tanaman (Gambar 2).

Berdasarkan deskripsinya, varietas Inpari 16 memperlihatkan karakter yang agak rentan terhadap serangan hama WBC jika dibandingkan dengan varietas yang lainnya (Inpari 42 dan lokal Kamba). $\mathrm{Hal}$ ini mengindikasikan bahwa varietas Inpari 42 dan varietas lokal Kamba memiliki karakteristik morfologi batang yang agak keras sehingga menyulitkan bagi wereng untuk mengisap cairan pada batang tanaman padi tersebut, beda halnya dengan varietas Inpari 16 dengan morfologi batang yang agak lunak sehingga hama WBC ini dengan mudahnya mengisap cairan pada batang sebagai sumber makanan bagi nimfa WBC. Sujitno dkk. (2014) melaporkan bahwa batang yang keras dan permukaan daun yang agak kasar merupakan sifat morfologi dari varietas tanaman yang tahan dan agak tahan sehingga kurang disukai oleh WBC. Hama WBC akan mengalami kesulitan saat mengisap cairan sel tanaman sehingga akan menyebabkan nimfa yang ada mati karena tidak memperoleh makanan.

Faktor penyebab munculnya serangan hama WBC ini diduga kondisi lahan yang lembab karena telah memasuki musim penghujan. Iklim mikro yang lembab merupakan habitat yang paling disukai oleh nimfa WBC untuk berkembang. Sejalan dengan yang dilaporkan Dianawati \& Sujitno (2015) bahwa faktor biotik dan abiotik, serta sistem budidaya padi yang diterapkan mendukung perkembangan dan juga memberikan pengaruh yang nyata dalam meningkatkan populasi dan serangan WBC.

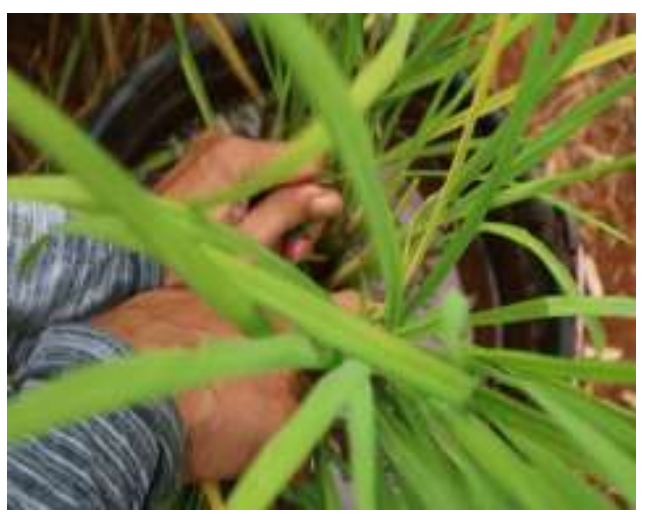

Gambar 7. Daun tampak menguning akibat gejala serangan Nilaparvata lugens.

Adapun pengendalian yang dilakukan adalah dengan memisahkan rumpun tanaman yang terserang dan yang tidak (Gambar 7). Air yang menggenangi dalam ember pada rumpun tanaman yang terserang dikeringkan terlebih dahulu selama seminggu agar tidak terlalu lembab sehingga populasi wereng menjadi berkurang. Habitat yang lembab sangat disukai oleh wereng batang coklat untuk berkembang. Selanjutnya dilakukan penyemprotan dengan insektisida berbahan aktif pymetrozine dan dinotefuran pada pagi atau sore hari (saat tidak turun hujan). Penyemprotan dilakukan sesuai dosis anjuran yang tepat dan langsung disemprotkan pada batang tanaman padi dimana nimfa wereng melekat.

\section{Hawar Daun Bakteri (HDB)}

Jenis penyakit yang menyerang tanaman padi di lokasi penelitian adalah hawar daun bakteri. Penyakit ini disebabkan bakteri Xanthomonas oryzae pv. oryzae (Xoo) yang utamanya menyerang bagian daun tanaman padi sawah. Penyakit HDB dapat menyebabkan penurunan hasil yang cukup signifikan 30-40\% (Yanti dkk., 2018) dengan tingkat kerusakan yang dapat mencapai 50\% (Khaeruni dkk., 2014). Berdasarkan hasil pengamatan, penyakit hawar daun bakteri menyerang tanaman padi pada saat fase pertumbuhan vegetative (Gambar 8). Varietas lokal Kamba memiliki reaksi ketahanan yang lebih baik dibandingkan padi VUB. Hal ini ditunjukkan dari hasil pengamatan sebesar 18,52\% rumpun daun tanaman padi varietas lokal yang terserang, sedangkan yang terbesar terdapat pada varietas Inpari 16 sebesar 50,62\% disusul varietas Inpari 42 sebesar 40,74\% (Gambar 2).

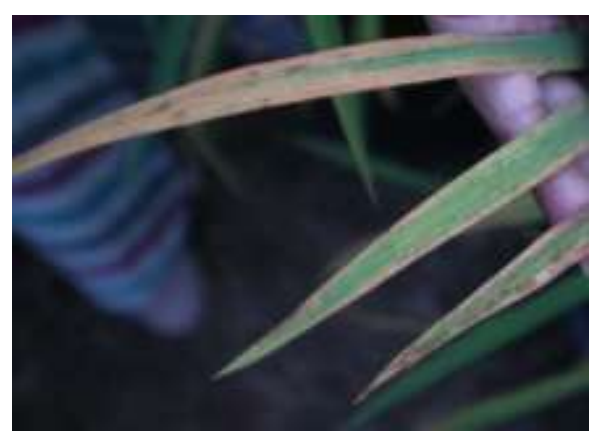

Gambar 8. Gejala serangan penyakit hawar daun bakteri oleh bakteri (Xanthomonas oryzae pv. oryzae).

Hal tersebut sejalan dengan hasil penelitian Rohaeni \& Yuliani (2019) yang melaporkan bahwa 
keragaman fenotipe yang lebih tinggi pada padi lokal dapat dijadikan sebagai karakter seleksi penciri sifat ketahanan terhadap HDB dibandingkan varietas modern atau varietas unggul. Samiullah et al. (2015) mengemukakan bahwa apabila dibandingkan dengan varietas unggul lama, padi lokal memiliki potensi untuk melawan penyakit HDB dan menunjukkan kinerja yang lebih baik secara kuantitatif.

Gejala dari penyakit hawar daun bakteri terbagi menjadi dua yaitu kresek (gejala muncul pada tanaman yang telah berumur 30 hari dari persemaian) dan hawar (muncul gejala pada saat tanaman telah mencapai fase tumbuh anakan hingga fase pemasakan). Gejala yang timbul ditandai dengan daun yang berwarna hijau keabu-abuan dan menggulung. Pada tanaman dewasa (gejala hawar) ditandai dengan warna daun akan berubah menjadi kuning jingga pada tepi daun, ujung daun kemudian menyebar dan memanjang ke pangkal daun (Khaeruni dkk., 2014). Selanjutnya bagian daun yang terinfeksi menjadi berwarna keabu-abuan dengan titik-titik hitam yang menandakan tumbuhnya cendawan saprofit (Nurkartika dkk., 2018).

Varietas unggul baru (Inpari 16) jika ditinjau dari deskripsinya, merupakan varietas yang tahan terhadap hawar daun bakteri patotipe III namun pada penelitian ini Inpari 16 memiliki tingkat serangan tertinggi yaitu 50,62\%. Hal ini diduga karena kemampuan patogen untuk membentuk strain baru yang lebih virulen sehingga penggunaan varietas yang tahan terhadap HDB menjadi kurang efektif.

Timbulnya gejala serangan hawar daun bakteri yang disebabkan oleh bakteri Xoo diduga karena kondisi iklim pada saat pengamatan mulai memasuki musim penghujan, sehingga lingkungan sekitar menjadi lembab. Kondisi kelembaban yang tinggi menyebabkan bakteri Xoo dapat berkembangbiak dengan baik. Salah satu pengendalian yang dilakukan untuk mengatasi gejala serangan penyakit ini adalah dengan mengatur pengairan pada media tanam dengan cara mengeringkan media tanam selama satu minggu berturut-turut kemudian satu minggu berikutnya digenangi lagi, dengan tujuan untuk menghindari kondisi yang terlalu lembab akibat penggenangan air secara terus menerus.

Selain itu sanitasi lingkungan di sekitar lokasi penelitian juga dilakukan dengan membersihkan gulma maupun sisa-sisa tanaman lain yang berada di lokasi tersebut. Sebagaimana diketahui bahwa patogen dapat bertahan hidup pada inang alternatif yang berupa gulma dan beberapa jenis tanaman yang lain. Pengendalian secara kimia juga dilakukan karena tingkat serangan yang terjadi mencapai $50 \%$ yaitu dengan melakukan penyemprotan bakterisida (anti-bakteri) yang memiliki kandungan copper hydroxide, kemudian untuk mengobati jaringan tanaman dari dalam dilakukan penyemprotan bakterisida sistemik berbahan aktif streptomycin sesuai dosis anjuran dan waktu yang tepat.

\section{SIMPULAN}

Perbedaan potensi serangan OPT pada tanaman padi VUB dan varietas lokal sangat dipengaruhi oleh faktor genetik dari tanaman itu sendiri, faktor lingkungan (keberadaan gulma dan jenis tanaman lain di sekitar lokasi penelitian) serta dipengaruhi oleh kondisi iklim. Serangan OPT $L$. migratoria, $S$. inferens, $N$. lugens dan penyakit hawar daun bakteri (HDB) pada tanaman padi terjadi pada saat fase pertumbuhan vegetatif sedangkan $C$. medinalis menyerang pada saat fase pertumbuhan generatif (fase pembungaan). Persentase tingkat serangan tertinggi terdapat pada VUB Inpari 16 dan Inpari 42 yang terserang HDB sebesar 50,62\% dan 40,74\% sedangkan varietas lokal Kamba yang diamati memiliki reaksi ketahanan yang agak baik terhadap serangan berbagai OPT dengan persentase serangan $\leq 25 \%$. Pengendalian sebaiknya dilakukan dengan memperhatikan kondisi lingkungan, jika belum melewati ambang batas serangan sebaiknya pengendalian secara kimiawi tidak direkomendasikan. Penanaman varietas padi perlu dipertimbangkan dengan mengikuti rekomendasi teknologi spesifik lokasi dan musim untuk tiap varietas, namun apabila terjadi perubahan iklim yang ekstrim perlu diantisipasi dengan menyiapkan teknologi yang tepat dan cepat. Hasil penelitian ini dapat dijadikan referensi dan sumber informasi untuk mengetahui keragaman OPT pada kultivar yang berbeda serta bagaimana tehnik pengendalian secara efektif dan efisien yang berwawasan lingkungan dalam percobaan semi lapangan.

\section{UCAPAN TERIMA KASIH}

Penulis mengucapkan terima kasih kepada semua pihak yang telah membantu proses pelaksanaan penelitian ini hingga selesai. Lembaga Pengelola Dana Pendidikan (LPDP) Kementerian 
Keuangan sebagai penyandang dana selama penelitian berlangsung sehingga berjalan dengan lancar.

\section{DAFTAR PUSTAKA}

Aryantini, L, I Supartha, dan I Wijaya. 2015. Kelimpahan populasi dan serangan penggerek batang padi pada tanaman padi di Kabupaten Tabanan. E-Jurnal Agroekoteknologi Tropika (Journal of Tropical Agroecotechnology). 4(3): 203212.

Arzam, ST, SM Yasin, S Sapareng, Rino, MY Idris, dan Yasmin. 2017. Karakteristik padi lokal aromatik di Kecamatan Seko. Journal TABARO. 1(2): 118-126.

Baehaki. 2005. Penampilan hama pelipat daun Cnapbalocrosis medinalis imigran dan parasitoid Elasmus sp. di pertanaman padi. Jurnal Entomol Indonesia. 2(1): 1-9.

Baehaki. 2013. Hama penggerek batang padi dan teknologi pengendalian. Iptek Tanaman Pangan. 8 (1): 1-14.

Darmadi, D, dan $\mathrm{T}$ Alawiyah. 2018. Respons beberapa varietas padi (Oryza sativa L.) terhadap wereng batang coklat (Nilaparvata lugens Stall) koloni karawang. Agrikultura. 29(2): 73-81.

Dianawati, M, dan E Sujitno. 2015. Kajian berbagai varietas unggul terhadap serangan wereng batang coklat dan produksi padi di lahan sawah Kabupaten Garut, Jawa Barat. Prosiding Seminar Nasional Masyarakat Biodiversitas Indonesia. 1(4): 868-873.

Hadi, M, RH Soesilohadi, F Wagiman, dan YR Soehardjono,. 2015. Populasi penggerek batang padi pada ekosistem sawah organik dan sawah anorganik. Bioma: Berkala Ilmiah Biologi. 17(2): 106-117.

Harini, AS, SS Kumar, P Balaravi, R Sharma, MA Dass, and V Shenoy. 2013. Evaluation of rice genotypes for brown planthopper $(\mathrm{BPH})$ resistance using molecular markers and phenotypic methods. African Journal of Biotechnology. 12(19): 2515-2525.

Khaeruni, A, M Taufik, T Wijayanto, dan E Johan. 2014. Perkembangan penyakit hawar daun bakteri pada tiga varietas padi sawah yang diinokulasi pada beberapa fase pertumbuhan. Jurnal Fitopatologi Indonesia. 10(4): 119-125.

Kilala, A, CL Salaki, CS Rante, JB Kaligis, dan MF
Dien. 2015. Populasi dan serangan hama putih palsu Cnaphalocrosis medinalis (Guenee) pada tanaman padi sawah di Kecamatan Dumoga Timur Kabupaten Bolaang Mongondow. Cocos: 6(13): 1-8.

Maghfiratul, S, Suharto, dan Wagiyana. 2017. Efektivitas agensia pengendali hayati dan insektisida sintetik terhadap hama tanaman padi (Oryza sativa L.) di Kecamatan Mayang Kabupaten Jember. Gontor AGROTECH Science Journal. 3(2): 23-37.

Nik, N, A Rusae, dan B Atini. 2017. Identifikasi hama dan aplikasi bioinsektisida pada belalang kembara (Locusta migratoria, L) sebagai model pengendalian hama terpadu pada tanaman sorgum. Savana Cendana Jurnal Pertanian Konservasi Lahan Kering. 2(3): 46-47.

Ningsih, NF, E Ratnasari, dan U Faizah. 2016. Pengaruh ekstrak daun kumis kucing (Orthosiphon aristatus) terhadap mortalitas hama wereng coklat (Nilaparvata lugens). Lentera Bio. 5(1): 14-19.

Nurkartika, R, S Ilyas, and M Machmud. 2018. Aplikasi agens hayati untuk mengendalikan hawar daun bakteri pada produksi benih padi. Jurnal Agronomi Indonesia. 45(3): 235-242.

Nuryanto, B. 2018. Pengendalian penyakit tanaman padi berwawasan lingkungan melalui pengelolaan komponen epidemik. Jurnal Penelitian dan Pengembangan Pertanian. 37(1): 1-12.

Prakoso, B. 2017. Biodiversitas belalang (Acrididae: Ordo Orthoptera) pada agroekosistem (Zea mays L.) dan ekosistem hutan tanaman. Biosfera. 34(2): 80-88.

Putra, OD, S Samudin, dan I Lakani. 2014. Karakterisasi genotip padi lokal Kamba asal dataran Lore. E-J. Agrotekbis. 2(2): 146-154.

Rahmawati, S, dan IH Slamet-Loedin. 2006. Introduksi gen cryIB-cryIAa ke dalam genom padi (Oryza sativa L.) cv. Rojolele menggunakan transformasi agrobacterium. HAYATI Journal of Biosciences. 13(1): 1925.

Rahmiyati. 2006. Cara Pengendalian penggerek batang padi dengan menggunakan cendawan Beauveria bassiana. Temu Teknis Nasional Tenaga Fungsional Pertanian Pusat Penelitian dan Pengembangan Peternakan. Hlm. 394-397.

Rohaeni, WR, and D Yuliani. 2019. Keragaman 
morfologi daun padi lokal indonesia dan korelasinya dengan ketahanan penyakit hawar daun bakteri. Jurnal Ilmu Pertanian Indonesia. 24(3): 258-266.

Samiullah, A Rafi, M Salman, M Sarwar, A Umar, A Hussain, Habibullah, M Nazir, SM Hussain, Ayatullah, M Nasir, and I Akbar. 2015. Evaluation of Indigenous Rice Germplasm for Resistance to Bacterial Leaf Blight and Yield Performance. Journal of Entomology and Zoology Studies. 3(4): 449-453.

Sujitno, E, M Dianawati, dan T Fahmi. 2014. Serangan wereng batang coklat pada padi varietas unggul baru lahan sawah irigasi. Agros. 16(2): 240-247.

Suparwoto, Harnisah, dan Setiawan, U. 2017. Adaptasi tiga varietas inpari di lahan tadah hujan Desa Cahaya Maju Kabupaten Ogan Komering Ilir Sumatera Selatan. Prosiding Seminar Nasional Lahan Suboptimal 2017. Palembang 19-20 Oktober 2017. Hlm. 708-
715.

Supriyanto, S. 2019. Pengeluaran untuk konsumsi penduduk Indonesia. Susenas Maret 2019 dalam N. Sahrizal dan I. Sahara (Eds.). 2019. Badan Pusat Statistik. Tersedia online pada https://www.bps.go.id. Diakses Januari 2020.

Surtikanti. 2011. Hama dan penyakit penting tanaman jagung dan pengendaliannya. Seminar Nasional Serealia. Hlm. 497-508.

Tangkilisan, VE, CL Salaki, MF Dien, dan ERM Meray. 2013. Serangan hama putih palsu Cnaphalocrosis medinalis Guenee. pada tanaman padi sawah di Kecamatan Ranoyapo Kabupaten Minahasa Selatan. Eugenia. 19(3): 23-29.

Yanti, S, M Marlina, dan F Fikrinda. 2018. Pengendalian penyakit hawar daun bakteri pada padi sawah menggunakan fungi mikoriza. Jurnal Agroecotania. 1(2): 14-21. 